\title{
Jurist-Diction
}

Volume 3 No. 6, November 2020

\section{Perlindungan Hukum Saksi Pelapor Tindak Pidana Korupsi Dalam Konteks Peraturan Perundang-Undangan}

\author{
How to cite: \\ Ilham Rahmansyah \\ 'Perlindungan Hukum Saksi \\ Pelapor Tindak Pidana Korupsi \\ Dalam Konteks Peraturan \\ Perundang-Undangan' (2020) \\ Vol. 3 No. 6 November Jurist- \\ Diction. \\ Histori artikel: \\ Submit 09 Agustus 2020; \\ Diterima 12 September 2020; \\ Diterbitkan 1 November 2020 \\ DOI: \\ 10.20473/jd.v3i6.22969
}

\author{
Ilham Rahmansyah \\ ilham.rahmansyah-2016@fh.unair.ac.id \\ Universitas Airlangga
}

\begin{abstract}
Abstrak
Saksi Pelapor atau Whistleblower Tindak Pidana adalah pihak yang mengetahui dan melaporkan tindak pidana tertentu dan bukan merupakan bagian dari pelaku kejahatan yang dilaporkannya. Berkaitan dengan pelaporan dugaan tindak pidana korupsi, pada dasarnya masyarakat bertanggung jawab memberikan informasi adanya dugaan telah terjadi tindak pidana korupsi (pelapor tindak pidana korupsi). Melaporkan adanya dugaan tindak pidana korupsi bukanlah suatu larangan melainkan keharusan. Whistleblower atau saksi pelapor tidak dapat dituntut secara hukum baik pidana maupun perdata atas laporan, kesaksian yang akan, sedang atau yang telah diberikannya.

Kata Kunci: Saksi Pelapor; Whistleblower; Korupsi.
\end{abstract}

\section{Pendahuluan}

Korupsi sendiri secara konseptual dapat diartikan sebagai suatu perbuatan melawan hukum yang dimana orang atau sekelompok orang yang melakukannya dengan sengaja memperkaya diri sendiri atau orang lain, dengan menggunakan pengaruhnya atau menyalahgunakan kewenangannya pada konteks penyelenggaraan negara dalam rangka memperkaya diri sendiri atau orang lain atau menguntungkan diri sendiri atau orang lain dimana jelas terdapat unsur kerugian keuangan negara dan dapat dilakukan secara terstruktur, sistematis dan masif. Sehingga tindak pidana korupsi dapat diklasifikasikan sebagai kejahatan luar biasa (extra ordinary crime). ${ }^{1}$

Sebagai hukum pidana khusus ${ }^{2}$ (lex spesialis) dan karena konteksnya yang merupakan kejahatan luar biasa inilah, maka penyelidikan, penyidikan, penuntutan

1 R. Wiyono, Tindak Pidana Korupsi Di Indonesia (Alumni 1982).[5].

2 Didik Purwo Endroleksosno, Hukum Pidana (Airlangga University Press 2013).[17]. 
hingga pembuktian di persidangan menjadi proses yang sangat penting untuk dicermati sehingga dalam hal mencari kebenaraan materiil bisa terlaksana dengan baik. Namun dalam praktiknya, penyidik juga banyak mengalami kesulitan dalam melakukan investigasi dan mencari alat bukti karena sifatnya yang merupakan kejahatan luar biasa tadi, maka orang atau sekelompok orang yang melakukannya tentu akan berusaha menutupi jejaknya atau membersihkan dari dugaan yang ada dengan cara yang terstruktur, sistematis dan masif bisa dengan cara menggunakan pengaruh politiknya atau kekuatan ekonominya atau justru menggunakan caracara yang keji (intimidasi; kekerasan; penganiayaan; percobaan pembunuhan; pembunuhan; pembunuhan berencana). ${ }^{3}$

Alat bukti yang sah menurut KUHAP dapat dilihat pada Pasal 183 dan Pasal 184 ayat (1) KUHAP. Pada Pasal 184 ayat (1) KUHAP telah dibuktikan secara limitatif alat-alat bukti yang sah menurut undang-undang yaitu:
a. Keterangan Saksi;
b. Keterangan Ahli;
c. Surat;
d. Petunjuk;
e. Keterangan Terdakwa.

Hukum pembuktian tindak pidana korupsi, disamping tetap menggunakan hukum pembuktian umum yang ada didalam KUHAP. Dalam hal-hal tertentu berlaku pula hukum pembuktian khusus sebagai perkecualiannya. Adapun hukum penyimpangan pembuktian yang ada dalam hukum pidana korupsi, terdapat pada 2 (dua) hal, yaitu:

a. Mengenai bahan-bahan yang dapat digunakan untuk membentuk alat bukti petunjuk;

b. Mengenai sistem pembebanan pembuktian.

Menurut hukum pembuktian tindak pidana korupsi, bahan alat bukti diperluas lagi, selain menganut dasar hukum dalam Pasal 184 ayat (1) KUHAP juga menganut dasar hukum dalam Pasal 26A UU No. 31 Tahun 1999 yang diubah dengan UU No.

3 ibid. 
20 Tahun 2001 menentukan bahwa alat bukti petunjuk juga dapat dibentuk dari 2 (dua) alat bukti lain dari Pasal 188 ayat (2) KUHAP, yaitu:

a. Informasi yang diucapkan, dikirim, diterima atau disimpan secara elektronik dengan alat optik atau yang serupa dengan itu;

b. Dokumen, yakni setiap rekaman data atau informasi yang dapat dilihat, dibaca, dan atu didengar yang dapat dikeluarkan dengan atau tanpa bantuan suatu sarana, baik yang tertuang diatas kertas, benda fisik apapun selain kertas, maupun yang terekam secara elektronik, yang merupakan tulisan, suara, gambar, peta, rancangan, foto, huruf, tanda, angka, atau perforasi yang memiliki makna.

Sedangkan sistem pembebanan pembuktian ${ }^{4}$ tindak pidana korupsi menganut sistem pembebanan pembuktian terbalik. Artinya, dalam hukum pidana korupsi dan hukum acara pidana korupsi sebagai suatu yang bersifat lex specialis lebih menganut sistem pembebanan pembuktian (burden of proof). Pada dasarnya tetap mengacu pada Pasal 183 KUHAP, namun dalam sistem pembebanan pembuktian yang khusus dan lain dari hukum pembuktian umum, memuat ketentuan pihak mana (penuntut umum atau terdakwa) yang dibebani kewajiban untuk membuktikan telah terjadi atau tidak terjadinya suatu tindak pidana korupsi.

Keterangan saksi sebagai alat bukti ialah apa yang saksi nyatakan di sidang pengadilan. Namun dalam hal mencari kebenaran materiil pemeriksaan saksi di tingkat penyidikan juga penting. Penyidik karena kewajibannya mempunyai wewenang memanggil orang untuk didengar dan diperiksa sebagai tersangka atau saksi.

Di tingkat penyidikan, pemeriksaan saksi harus dibuatkan berita acaranya. Dasar hukum pemeriksaaan saksi di tingkat penyidikan adalah Pasal 112 KUHAP yang berbunyi: (1) Penyidik yang melakukan pemeriksaan, dengan menyebutkan alasan pemanggilan secara jelas, berwenang memanggil tersangka dan saksi yang dianggap perlu untuk diperiksa dengan surat panggilan yang sah dengan memperhatikan tenggang waktu yang wajar antara diterimanya panggilan dan hari seorang itu diharuskan memenuhi panggilan tersebut; (2) Orang yang dipanggil

\footnotetext{
4 Andi Hamzah, Hukum Acara Pidana Indonesia (Sinar Grafika 2016).[260].
} 
wajib datang kepada penyidik dan jika ia tidak datang, penyidik memanggil sekali lagi, dengan perintah kepada petugas untuk membawa kepadanya.

Jika seorang tersangka atau saksi yang dipanggil memberi alasan yang patut dan wajar bahwa ia tidak dapat datang kepada penyidik yang melakukan pemeriksaan, penyidik itu datang ke tempat kediamannya. Saksi diperiksa dengan tidak disumpah kecuali apabila ada cukup alasan untuk diduga bahwa ia tidak akan dapat hadir dalam pemeriksaan di pengadilan. Saksi diperiksa secara tersendiri, tetapi boleh dipertemukan yang satu dengan yang lain dan mereka wajib memberikan keterangan yang sebenarnya. Dalam pemeriksaan tersangka ditanya apakah ia menghendaki didengarnya saksi yang dapat menguntungkan baginya dan bilamana ada maka hal itu dicatat dalam berita acara.

Saksi Pelapor atau Whistleblower memiliki peran penting dalam mengungkap fakta dalam suatu dugaan atau perkara tindak pidana korupsi sehingga, perlunya perlindungan terhadap saksi pelapor atau whistleblower juga menjadi penting, apalagi hari ini ada beberapa kasus yang mengganggu proses pemeriksaan dan pembukaian dengan cara mengintimidasi, kekerasan fisik bahkan tuntutan balik dari orang yang merasa dirugikan akibat laporan dan aduan dari saksi pelapor pada perkara tindak pidana korupsi. Saksi pelapor tindak pidana korupsi yang statusnya harusnya dilindungi malah justru berstatus sebagai tersangka tindak pidana lain.

\section{Konsep Saksi Pelapor (Whistleblower) Menurut Perundang-undangan}

Saksi adalah orang yang dapat memberikan keterangan guna kepentingan penyelidikan, penyidikan, penuntutan, dan pemeriksaan di sidang pengadilan tentang suatu tindak pidana yang ia dengar sendiri, ia lihat sendiri, dan/atau ia alami sendiri. ${ }^{5}$ Pelapor adalah orang yang memberikan laporan, informasi, atau keterangan kepada penegak hukum mengenai tindak pidana yang akan, sedang, atau telah terjadi. ${ }^{6}$

Sedangkan berdasarkan Surat Edaran Mahkamah Agung RI Nomor 4 Tahun 2011 Tentang Perlakuan Bagi Pelapor Tindak Pidana (Whistleblower) dan

\footnotetext{
5 Kitab Undang-Undang Hukum Acara Pidana.

6 ibid.
} 
Saksi Pelaku yang Bekerjasama (Justice Collaborator) di dalam Tindak Pidana Tertentu yang keberlakuannya dipatuhi oleh seluruh lingkungan peradilan dibawah Mahkamah Agung menyebutkan, bahwa secara teknis konsep dari Saksi Pelapor (Whistleblower) sendiri adalah bersifat umum bagi tindak pidana tertentu. Tindak pidana tertentu yang dimaksud disini adalah tindak pidana kejahatan yang terorganisir yaitu; korupsi, pencucian uang, terorisme, narkotika, perdagangan orang dan tindak pidana kejahatan yang terorganisir lainnya. Dalam Surat Edaran tersebut, Mahkamah Agung menilai bahwa Saksi Pelapor (Whistleblower) khususnya pada tindak pidana korupsi perlu mendapatkan perhatian khusus dan perlindungan hukum.Sehingga dari konsep-konsep diatas, penulis mengambil kesimpulan bahwa konsep Saksi Pelapor (Whistleblower) Tindak Pidana Korupsi adalah; “Orang yang melihat, mendengar atau mengalami sendiri adanya tindak pidana korupsi yang kemudian diungkapkan ke publik atau dilaporkan kepada pihak yang berwenang atau aparat penegak hukum (APH). Secara umum pengertian orang yang mengungkapkan fakta (saksi pengungkap fakta) kepada publik mengenai sebuah skandal, bahaya, malpraktik, maladministrasi atau korupsi disebut whistleblower (Inggris artinya: peniup peluit). Whistleblower didefinisikan sebagai seorang yang memberikan bantuan kepada aparat penegak hukum dalam bentuk pemberian informasi penting, bukti-bukti yang kuat, atau keterangan di bawah sumpah yang dapat mengungkap suatu kejahatan dimana orang tersebut terlibat dalam kejahatan tersebut atau suatu kejahatan lainnya. Kejahatan yang terjadi biasanya merupakan sebuah skandal atau merupakan suatu jaringan sindikat sehingga whistleblower betul-betul mengetahui secara pasti kejahatan itu terjadi dan dapat membantu penegak hukum untuk membuktikan kejahatan tersebut. ${ }^{7}$

Seorang whistleblower seringkali dipahami sebagai saksi pelapor. Orang yang memberikan laporan atau kesaksian mengenai suatu dugaan tindak pidana kepada aparat penegak hukum dalam proses peradilan pidana. Whistleblower biasanya ditujukan kepada seseorang yang pertama kali mengungkap atau melaporkan suatu

7 Robert K, Aris Irawan, Hukum Perlindungan Saksi Dalam Pemberantasan Tindak Pidana Korupsi (Thafa Media 2019).[116]. 
tindak pidana atau tindakan yang dianggap ilegal di tempatnya bekerja atau orang lain berada, kepada otoritas internal organisasi atau perusahaan atau kepada aparat penegak hukum. Pengungkapan tersebut tidak selalu didasari itikad baik sang pelapor, tetapi tujuannya untuk mengungkap kejahatan atau penyelewengan yang diketahuinya, untuk itulah jika saksi pelapor tersebut ingin mengajukan permohonan perlindungan kepada LPSK, penting bagi LPSK agar mengidentifikasi terlebih dahulu yang bersangkutan berhak atu tidak. Dalam beberapa kasus, pelanggaran sudah terjadi dan peran whistleblower adalah melaporkannya. Namun, dalam kasuskasus lainnya, pelanggaran masih berbentuk dugaan, yang mungkin tidak terbukti bahkan salah. Sehingga perlu peran aparat penegak hukum untuk memastikannya.

Tindakan whistleblower berhubungan erat dengan korupsi, termasuk pelanggaran hukum, pemborosan sumber daya, penyalahgunaan kewenangan, tindakan curang, maladministrasi, tindakan yang membahayakan kesehatan dan keamanan publik atau lingkungan, tidak jujur, penyalahgunaan informasi dan penyalahgunaan kepercayaan. Bahkan serangan balik terhadap whistleblower adalah bentuk perilaku korup. Dengan demikian, whistleblowing adalah tindakan anti-korupsi. $^{8}$

Setelah mempelajari SEMA No. 4 Tahun 2011, yang menyamakan whistleblower dengan pelapor tindak pidana, dapat disimpulkan bahwa whistleblower adalah perkembangan dari pengertian pelapor, yaitu:

1. Jenis tindak pidana yang dilaporkan adalah tindak pidana tertentu, yang pembuktiannya tidak mudah;

2. Pelapornya adalah orang yang sangat dekat dengan para pelaku, tetapi tidak terlibat dalam tindak pidana tersebut;

3. Kedekatan tersebut menyebabkan pelapor memiliki informasi yang akurat sekaligus rentan terhadap serangan balasan;

4. Salah satu serangan balasan adalah menggunakan perangkat hukum, sehingga berpotensi menimbulkan ketidakpastian penegakan hukum.

KUHAP telah memberikan macam-macam jenis alat bukti yang dapat digunakan dalam sidang di pengadilan. Pasal 184 ayat (1) menyebutkan alat bukti

${ }^{8}$ Adami Chazawi, Hukum Pembuktian Tindak Pidana Korupsi (Media Nusa Creative 2018).[42]. 
yang sah meliputi: keterangan saksi, keterangan ahli, surat, petunjuk, keterangan terdakwa. Sesuai dengan ketentuan Pasal 184 ayat 1 KUHAP tersebut, bisa dipahami bahwa undang-undang menentukan 5 (lima) jenis alat bukti yang sah. Sehingga, diluar 5 (lima) jenis alat bukti ini tidak dibenarkan dipergunakan untuk membuktikan kesalahan terdakwa dalam sidang di pengadilan. Oleh karena itu, hakim harus hati-hati, cermat, dan matang menilai dan mempertimbangkan nilai pembuktian dengan memeriksa sampai dimana "Kekuatan Pembuktian" atau bewijskracht dari setiap alat bukti yang disebut dalam Pasal 184 KUHAP. ${ }^{9}$

Salah satu ketentuan yang mengatur bagaimana caranya, aparat penegak hukum melaksanakan tugas dibidang represif adalah hukum acara pidana yang mempunyai tujuan yaitu untuk mencari dan mendekati kebenaran materiil, yaitu kebenaran yang selengkap-lengkapnya dari suatu perkara pidana dengan menerapkan ketentuan hukum acara pidana secara jujur dan tepat dengan tujuan untuk mencari siapakah pelaku yang dapat didakwakan melakukan suatu pelanggaran hukum, dan selanjutnya meminta pemeriksaan dan putusan dari pengadilan guna menentukan apakah terbukti bahwa suatu tindak pidana telah dilakukan dan apakah orang yang didakwa itu dapat dihukum. ${ }^{10}$

Alat bukti keterangan saksi merupakan alat bukti yang sah yang diatur dalam Pasal 184 ayat (1) Undang-Undang Nomor 8 Tahun 1981 tentang Hukum Acara Pidana (“KUHAP”). Yang dimaksud dengan saksi, menurut Pasal 1 angka 26 KUHAP adalah orang yang dapat memberikan keterangan guna kepentingan penyidikan, penuntutan dan peradilan tentang suatu perkara pidana yang ia dengar sendiri, ia lihat sendiri dan ia alami sendiri.

Keterangan saksi sebagai alat bukti tersebut dipergunakan oleh aparat penegak hukum dalam usaha mencari kebenaran materil. Pada Pasal 183 dan Pasal 184 ayat (1) KUHAP disebutkan tentang alat-alat bukti yang sah. Kedua pasal tersebut dapat saya pahami bahwa hakim dalam menjatuhkan putusannya dapat berdasarkan atas kesaksian saja, yaitu sebagai saksi atau ahli seorang saksi dapat

\footnotetext{
9 Andi Hamzah, Hukum Acara Pidana Indonesia (Sinar Grafika 2016).[260].

10 ibid.
} 
didengar keterangannya sebagai saksi maupun sebagai ahli, misalnya seorang dokter yang mengadakan pembedahan mayat dalam hal ini ia akan menjadi saksi, yang menyebabkan ia menjadi saksi karena ia melihat langsung. Atau dia tidak menangani langsung namun sebagai Kepala Rumah Sakit yang memberikan kewenangan terhadap dokter yang menangani pembedahan mayat. Berdasarkan latar belakang tersebut maka perlu adanya suatu analisis mendalam terkait dengan pembuktian dan fungsi alat bukti serta sejauh mana peranan alat bukti tersebut bila digunakan hakim dalam memutus suatu perkara. ${ }^{11}$

Dalam Pasal 185 ayat (5) KUHAP dinyatakan bahwa baik pendapat maupun rekaan, yang diperoleh dari hasil pemikiran saja, bukan merupakan keterangan saksi. Didalam penjelasan Pasal 185 ayat (1) disebutkan; "Dalam keterangan saksi tidak termasuk keterangan yang diperoleh dari orang lain atau testimonium de auditu." Testimonium de auditu ${ }^{12}$ yaitu kesaksian atau keterangan karena mendengar dari orang lain. Pada prinsipnya testimonium de auditu tidak dapat diterima sebagai alat bukti. Saksi menurut KUHAP adalah orang yang dapat memberikan keterangan guna kepentingan penyidikan, penuntutan dan peradilan tentang suatu perkara pidana yang ia dengar sendiri, ia lihat sendiri, dan ia alami sendiri. Kemudian Putusan MK 65/PUU-VIII/2010 memperluasnya. ${ }^{13}$

Namun, berdasarkan Putusan Mahkamah Konstitusi Nomor 65/PUUVIII/2010 tentang Pengujian Undang-Undang Nomor 8 Tahun 1981 tentang Hukum Acara Pidana ("Putusan MK 65/PUU-VIII/2010”) makna saksi telah diperluas menjadi sebagai berikut: "Pasal 1 angka 26 KUHAP dan 27, Pasal 65, Pasal 116 ayat (3), (4), Pasal 184 ayat (1a) KUHAP bertentangan dengan Undang-Undang Dasar 1945 sepanjang tidak dimaknai termasuk pula “orang yang dapat memberikan keterangan dalam rangka penyidikan, penuntutan, dan peradilan suatu tindak pidana yang tidak selalu ia dengar sendiri, ia lihat sendiri dan ia alami sendiri”. Artinya,

\footnotetext{
${ }^{11}$ Andi Hamzah, Hukum Acara Pidana (Sinar Grafika 2016).[262].

12 ibid.

13 Bastianto Nugroho, 'Peranan Alat Bukti Dalam Perkara Pidana Dalam Putusan Hakim Menurut Kuhap’ (2017) 32 Yuridika.
} 
juga setiap orang yang punya pengetahuan yang terkait langsung terjadinya suatu tindak pidana wajib diperhatikan keterangannya sebagai saksi demi keadilan dan keseimbangan penyidik yang berhadapan dengan tersangka/terdakwa.

Peranan saksi dalam setiap proses di persidangan perkara pidana sangat penting, karena keterangan saksi dapat mempengaruhi dan menentukan kecenderungan keputusan hakim. Seorang saksi dianggap memiliki kemampuan yang dapat menentukan kemana arah putusan hakim. Dalam suatu proses peradilan pidana, saksi memegang peranan kunci dalam upaya mengungkap suatu kebenaran materil. Dalam Pasal 184 ayat (1) KUHAP, keterangan saksi ditempatkan pada urutan pertama. Pada saat saksi akan memberikan keterangan, tentunya harus diberi jaminan bahwa yang bersangkutan terbebas dari rasa takut sebelum, pada saat, dan setelah memberikan kesaksian.

Hal ini sejalan dengan pengertian dari saksi itu sendiri yang terdapat dalam Pasal 1 butir 26 KUHAP, yaitu “Orang yang dapat memberikan keterangan guna kepentingan penyidikan, penuntutan, dan peradilan tentang suatu perkara yang ia dengar sendiri, ia lihat sendiri, dan ia alami sendiri." Dari pengertian tersebut di dapat suatu kesimpulan bahwa setiap orang dapat menjadi saksi dan memberikan kesaksian tanpa mempedulikan status orang tersebut, termasuk tersangka atau terdakwa. Alat bukti keterangan saksi merupakan alat bukti yang paling utama dalam perkara pidana. Hampir semua pembuktian perkara pidana, selalu bersandar kepada pemeriksaan keterangan saksi, disamping pembuktian dengan alat bukti yang lain. Pasal 117 ayat (1) KUHAP mengatur: "Keterangan tersangkan dan atau saksi kepada penyidik diberikan tanpa tekanan dari siapapun dan atau dalam bentuk apapun." Pasal 118 ayat (1) KUHAP mengatur: “Keterangan tersangka dana tau saksi dicatat dalam berita acara yang ditanda tangani oleh penyidik, dan oleh yang memberi keterangan itu setelah mereka menyetujuinya."

Ketentuan yang diatur dalam Pasal 177 ayat (1) jo Pasal 118 ayat (1) ini ada kaitannya dengan Pasal 52 KUHAP. Dimana, dalam pengaturannya memberikan jaminan terhadap seorang saksi untuk memberikan keterangan secara bebas kepada penyidik atau hakim. Bahkan, diatur pula jika dalam hal salah satu pertanyaan 
yang disampaikan oleh penyidik kepada saksi dengan pertanyaan yang menjerat, mengarahkan, memberikan alternatif, atau menyebut kualifikasi juga tidak diperbolehkan dalam menggali keterangan saksi. Hal ini berlaku di berita acara pemeriksaan maupun dalam siding di pengadilan. Pasal 98 ayat (1) KUHAP mengatur: "Jika suatu perbuatan yang menjadi dasar dakwaan di dalam suatu pemeriksaan perkara pidana oleh pengadilan negeri menimbulkan kerugian bagi orang lain maka hakim ketua sidang atas permintaan orang itu dapat menetapkan untuk menggabungkan perkara gugatan ganti kerugian kepada perkara pidana itu." Pasal 277 ayat (1) KUHAP mengatur: "Semua jenis pemberitahuan atau panggilan oleh pihak yang berwenang dalam semua tingkat pemeriksaan kepada terdakwa, saksi atau ahli disampaikan selambat-lambatnya tiga hari sebelum tanggal hadir yang ditentukan ditempat tinggal mereka atau ditempat kediaman mereka berakhir.” Pasal 299 ayat (1) KUHAP mengatur: "Saksi atau ahli yang telah hadir memenuhi panggilan dalam rangka memberikan keterangan di semua tingkat pemeriksaan, berhak mendapat penggantian biaya menurut peraturan perundang-undangan yang berlaku."

Selanjutnya, sebagaimana disebut dalam Ketentuan Pasal 1 angka 1 UndangUndang No. 31 Tahun 2014 yang dimaksud dengan; "Saksi adalah orang yang dapat memberikan keterangan guna kepentingan penyelidikan, penyidikan, penuntutan, dan pemeriksaan di sidang pengadilan tentang suatu tindak pidana yang ia dengar sendiri, ia lihat sendiri, dan/atau ia alami sendiri."

Sedangkan pada Ketentuan Pasal 1 angka 4 Undang-Undang No. 31 Tahun 2014 yang dimaksud dengan: "Pelapor adalah orang yang memberikan laporan, informasi, atau keterangan kepada penegak hukum mengenai tindak pidana yang akan, sedang, atau telah terjadi."

Dalam Undang-Undang No. 31 Tahun 2014 juga dijelaskan, selain Saksi dan Korban, ada pihak lain yang juga memiliki kontribusi besar untuk mengungkap tindak pidana tertentu, yaitu Saksi Pelaku (justice collaborator), Pelapor (whistleblower), dan ahli, termasuk pula orang yang dapat memberikan keterangan yang berhubungan dengan suatu perkara pidana meskipun tidak ia dengar sendiri, 
tidak ia lihat sendiri, dan tidak ia alami sendiri, sepanjang keterangan orang itu berhubungan dengan tindak pidana, sehingga terhadap mereka perlu diberikan Perlindungan.

Pelaksanaan peran serta masyarakat dalam upaya pencegahan dan pemberantasan tindak pidana korupsi dimaksudkan agar tercipta penyelenggaraan negara yang bersih dan bebas dari KKN bukan/hanya tanggung jawab dari penyelenggara negara semata, melainkan juga masyarakat.

Sebagaimana diatur dalam Ketentuan Pasal 31 ayat (1) jo Pasal 41 ayat (1) dan ayat (2) Undang-Undang Nomor 20 Tahun 2001 Tentang Perubahan Atas Undang-Undang Nomor 31 Tahun 1999 Tentang Pemberantasan Tindak Pidana Korupsi: "Pasal 31 mengatur; (1) Dalam penyidikan dan pemeriksaan di sidang pengadilan, saksi dan orang lain yang bersangkutan dengan tindak pidana korupsi dilarang menyebut nama atau alamat pelapor, atau hal-hal lain yang memberikan kemungkinan dapat diketahuinya identitas pelapor. Penjelasan Pasal 31 ayat (1) menjelaskan; Yang dimaksud dengan "pelapor" dalam ketentuan ini adalah orang yang memberi informasi kepada penegak hukum mengenai terjadinya suatu tindak pidana korupsi dan bukan pelapor sebagaimana dimaksud dalam Pasal 1 angka 24 Undang-undang Nomor 8 Tahun 1981 tentang Hukum Acara Pidana”.

Dalam Ketentuan Pasal 41 ayat (1) jo dan (2) Undang-Undang Nomor 20 Tahun 2001 Tentang Perubahan Atas Undang-Undang Nomor 31 Tahun 1999 Tentang Pemberantasan Tindak Pidana Korupsi, dapat dipahami bahwa dalam upaya pencegahan dan pemberantasan tindak pidana korupsi, masyarakat mempunyai hak dan tanggung jawab berperan serta dalam upaya pencegahan dan pemberantasan tindak pidana korupsi. Peran serta masyarakat dalam upaya pencegahan dan pemberantasan diwujudkan dalam bentuk antara lain; mencari, memperoleh, memberikan data, atau informasi tentang tindak pidana korupsi dan hak menyampaikan saran dan pendapat serta bertangung jawab terhadap pencegahan dan pemberantasan pada tindak pidana korupsi.

Peran serta masyarakat dalam pemberantasan korupsi telah dikembangkan melalui Peraturan Pemerintah Nomor 43 tahun 2018 tentang Tata Cara Pelaksanaan 
Peran Serta Masyarakat dan Pemberian Penghargaan dalam Pencegahan dan Pemberantasan Tindak Pidana Korupsi.

\section{Perlindungan Hukum Saksi Pelapor (Whistleblower) Tindak Pidana Korupsi}

Jika kita melihat peraturan perundang-undangan, ada beberapa instrumen perlindungan hukum bagi saksi pelapor (Whistleblower) pada perkara tindak pidana korupsi, yakni sebagai berikut:

1. Undang-Undang No. 28 Tahun 1999 Tentang Penyelenggaraan Negara yang Bersih dan Bebas dari Korupsi, Kolusi, dan Nepotisme;

2. Undang-Undang No. 31 Tahun 1999 Tentang Pemberantasan Tindak Pidana Korupsi jo Undang-Undang No. 20 Tahun 2001 Tentang Perubahan Atas UndangUndang No. 31 Tahun 1999 Tentang Pemberantasan Tindak Pidana Korupsi;

3. Konvensi Perserikatan Bangsa-Bangsa Anti Korupsi sebagaimana telah diratifikasi melalui Undang-Undang No. 7 Tahun 2006 Tentang Pengesahan United Nations Conventions Against Corruption, 2003;

4. Undang-Undang No. 31 Tahun 2014 Tentang Perubahan Atas Undang-Undang No. 13 Tahun 2006 Tentang Perlindungan Saksi dan Korban.

Sebagaimana telah diatur melalui UU No. 28 Tahun 1999 Tentang Penyelenggaraan Negara yang Bersih dan Bebas dari Korupsi, Kolusi, dan Nepotisme Pasal 9 dijelaskan; Pasal 9 ayat (1) mengatur mengenai Peran serta masyarakat sebagaimana dimaksud dalam Pasal 8 diwujudkan dalam bentuk:

a. hak mencari, memperoleh, dan memberikan informasi tentang penyelenggaraan negara;

b. hak untuk memperoleh pelayanan yang sama dan adil dari Penyelenggara Negara;

c. hak menyampaikan saran dan pendapat secara bertanggungjawab terhadap kebijakan Penyelenggara Negara;

d. hak memperoleh perlindungan hukum dalam hal:

(1)Melaksanakan haknya sebagaimana dimaksud dalam huruf a, b, c;

(2)Diminta hadir dalam proses Penyelidikan, penyidikan, dan di sidang pengadilan sebagai saksi pelapor, saksi, atau saksi ahli, sesuai dengan ketentuan peraturan perundang-undangan yang berlaku.

Didalam penjelasan Pasal 9 ayat (1) dijelaskan: "Ketentuan dalam ayat (1) huruf d angka (2) merupakan suatu kewajiban bagi masyarakat yang oleh Undangundang ini diminta hadir dalam proses Penyelidikan, penyidikan, dan di sidang pengadilan sebagai saksi pelapor, saksi, atau saksi ahli. Apabila oleh pihak yang 
berwenang dipanggil sebagai saksi pelapor, saksi, atau saksi ahli dengan sengaja tidak hadir, maka dikenakan sanksi sesuai dengan ketentuan peraturan perundangundangan yang berlaku".

Selanjutnya, sebagaimana telah diatur melalui UU No. 31 Tahun 1999 Tentang Pemberantasan Tindak Pidana Korupsi (PTPK) jo Undang-Undang No. 20 Tahun 2001 Tentang Perubahan Atas Undang-Undang No. 31 Tahun 1999 Tentang Pemberantasan Tindak Pidana Korupsi Pasal 41; (1) Masyarakat dapat berperan serta membantu upaya pencegahan dan pemberantasan tindak pidana korupsi. (2) Peran serta masyarakat sebagaimana dimaksud dalam ayat (1) diwujudkan dalam bentuk:

a. hak mencari, memperoleh, dan memberikan informasi adanya dugaan telah terjadi tindak pidana korupsi;

b. hak untuk memperoleh pelayanan dalam mencari, memperoleh dan memberikan informasi adanya dugaan telah terjadi tindak pidana korupsi kepada penegak hukum yang menangani perkara tindak pidana korupsi;

c. hak menyampaikan saran dan pendapat secara bertanggung jawab kepada penegak hukum yang menangani perkara tindak pidana korupsi;

d. hak untuk memperoleh jawaban atas pertanyaan tentang laporannya yang diberikan kepada penegak hukum dalam waktu paling lama 30 (tiga puluh) hari;

e. hak untuk memperoleh perlindungan hukum dalam hal:

(1) melaksanakan haknya sebagaimana dimaksud dalam huruf a, b, c;

(2) diminta hadir dalam proses penyelidikan, penyidikan, dan di sidang pengadilan sebagai saksi pelapor, saksi, atau saksi ahli, sesuai dengan ketentuan peraturan perundang-undangan yang berlaku;

(3) Masyarakat sebagaimana dimaksud dalam ayat (1) mempunyai hak dan tanggung jawab dalam upaya pencegahan dan pemberantasan tindak pidana korupsi;

(4) Hak dan tanggung jawab sebagaimana dimaksud dalam ayat (2) dan ayat (3) dilaksanakan dengan berpegang teguh pada asas-asas atau ketentuan yang diatur dalam peraturan perundang-undangan yang berlaku dan dengan menaati norma agama dan norma sosial lainnya;

(5) Ketentuan mengenai tata cara pelaksanaan peran serta masyarakat dalam pencegahan dan pemberantasan tindak pidana korupsi sebagaimana dimaksud dalam Pasal ini, diatur lebih lanjut dengan Peraturan Pemerintah.

Didalam penjelasan Pasal 41 ayat (1) dijelaskan: "Ketentuan dalam pasal ini dimaksudkan untuk meningkatkan efektifitas pencegahan dan pemberantasan tindak pidana korupsi." Selanjutnya didalam penjelasan ayat (2) huruf e: "Perlindungan hukum terhadap pelapor dimaksudkan untuk memberikan rasa aman bagi pelapor yang dilaksanakan sesuai dengan ketentuan peraturan perundang-undangan”. 
Selanjutnya, sebagimana telah diatur melalui Ketentuan Pasal 32 dan 33 Konvensi Perserikatan Bangsa-Bangsa Anti Korupsi sebagaimana telah diratifikasi melalui Undang-Undang No. 7 Tahun 2006 Tentang Pengesahan United Nations Conventions Against Corruption, 2003;

Pasal 32 angka 1: "Negara Pihak wajib mengambil tindakan-tindakan yang perlu sesuai dengan sistem hukum nasionalnya dan kemampuannya, untuk memberikan perlindungan yang efektif terhadap kemungkinan pembalasan atau intimidasi, bagi saksi dan ahli yang memberikan kesaksian mengenai kejahatan menurut Konvensi ini dan, sepanjang perlu, bagi keluarganya serta orang orang lain yang dekat dengannya." Pasal 33: "Negara Pihak wajib mempertimbangkan untuk memasukkan ke dalam sistem hukum nasionalnya tindakan-tindakan yang perlu untuk memberikan perlindungan terhadap perlakuan yang tidak adil bagi orang yang melaporkan dengan itikad baik dan dengan alasan-alasan yang wajar kepada pihak yang berwenang fakta-fakta mengenai kejahatan menurut Konvensi ini.”

Selanjutnya, sebagaimana telah diatur melalui Ketentuan Pasal 10 UndangUndang No. 31 Tahun 2014 Tentang Perubahan Atas Undang-Undang No. 13 Tahun 2006 Tentang Perlindungan Saksi dan Korban; (1) Saksi, Korban, Saksi Pelaku, dan/atau Pelapor tidak dapat dituntut secara hukum, baik pidana maupun perdata atas kesaksian dan/atau laporan yang akan, sedang, atau telah diberikannya, kecuali kesaksian atau laporan tersebut diberikan tidak dengan itikad baik. (2) Dalam hal terdapat tuntutan hukum terhadap Saksi, Korban, Saksi Pelaku, dan/atau Pelapor atas kesaksian dan/atau laporan yang akan, sedang, atau telah diberikan, tuntutan hukum tersebut wajib ditunda hingga kasus yang ia laporkan atau ia berikan kesaksian telah diputus oleh pengadilan dan memperoleh kekuatan hukum tetap.

Didalam penjelasan Pasal 10 dijelaskan: "Yang dimaksud dengan "memberikan kesaksian tidak dengan iktikad baik" antara lain memberikan keterangan palsu, sumpah palsu, dan permufakatan jahat." Penulis meyakini setelah membaca ketentuan tersebut bahwa unsur yang diatur disini sudah cukup memenuhi unsur sebagaimana yang dimaksud dengan tidak beritikad baik tersebut. Untuk mengujinya maka kita bisa melihat ketika yang bersangkutan mengajukan 
diri sebagai terlindung LPSK atau jika dikonfrontir saat pemeriksaan di sidang pengadilan dari keterangannya pada saat itu dengan apa yang telah ada dalam berita acara pemeriksaan.

Lembaga Perlindungan Saksi dan Korban berwenang memastikan pemberian perlindungan bagi saksi dan korban termasuk dalam hal ini saksi pelapor (whistleblower). Berdasarkan tugas dan kewenangannya, LPSK berwenang memberikan perlindungan sesuai yang diatur dalam Ketentuan Pasal 5 UndangUndang No. 31 Tahun 2014 sebagai berikut:

a. memperoleh perlindungan atas keamanan pribadi, keluarga dan harta bendanya, serta bebas dari ancaman yang berkenaan dengan kesaksian yang akan, sedang, atau telah diberikannya;

b. ikut serta dalam proses memilih dan menentukan bentuk perlindungan dan dukungan keamanan;

c. memberikan keterangan tanpa tekanan;

d. mendapat penerjemah;

e. bebas dari pertanyaan yang menjerat;

f. mendapat informasi mengenai perkembangan kasus;

g. mendapat informasi mengenai putusan pengadilan;

h. mendapat informasi dalam hal terpidana dibebaskan;

i. dirahasiakan identitasnya;

j. mendapat identitas baru;

k. mendapat tempat kediaman sementara;

1. mendapat tempat kediaman baru;

m. memperoleh penggantian biaya transportasi sesuai kebutuhan;

n. mendapat nasehat hukum;

o. memperoleh bantuan biaya hidup sementara sampai batas waktu perlindungan berakhir; dan/atau

p. mendapat pendampingan. ${ }^{14}$

Sedangkan ketentuan mengenai syarat pengajuan permohonan perlindungan saksi diatur dalam Ketentuan Pasal 28 Undang-Undang No. 31 Tahun 2014 sebagai berikut:

a. sifat pentingnya keterangan saksi dan/atau korban;

b. tingkat ancaman yang membahayakan saksi dan/atau korban;

c. hasil analisis tim medis atau psikolog terhadap saksi dan/atau korban; dan;

d. rekam jejak tindak pidana yang pernah dilakukan saksi dan/atau korban. ${ }^{15}$

\footnotetext{
${ }^{14}$ Undang-Undang No. 31 Tahun 2014.

15 ibid.
} 
Setelah melihat ketentuan diatas, juga diatur mengenai tata cara memperoleh perlindungan sebagaimana yang telah diatur dalam Ketentuan Pasal 29 ayat (1) Undang-Undang No. 31 Tahun 2014 sebagai berikut:

a. Saksi dan/atau Korban yang bersangkutan, baik atas inisiatif sendiri maupun atas permintaan pejabat yang berwenang, mengajukan permohonan secara tertulis kepada LPSK;

b. LPSK segera melakukan pemeriksaan terhadap permohonan sebagaimana dimaksud pada huruf a; dan

c. Keputusan LPSK diberikan secara tertulis paling lambat 7 (tujuh) hari sejak permohonan Perlindungan diajukan. ${ }^{16}$

Undang-Undang No. 31 tahun 2014 memang sudah mengatur secara baik, namun sifatnya masih terlalu umum mengenai mekanisme atau proses pengajuan permohonan dan bagaimana LPSK bisa memberikan keputusan sesuai Ketentuan Pasal 29 ayat (1) huruf c. Sehingga penting bagi LPSK menerbitkan Peraturan LPSK No. 6 Tahun 2010 Tentang Tata Cara Pemberian Perlindungan Saksi dan Korban.

Hal ini dapat dilihat misalnya pada Ketentuan Pasal 9 Peraturan ini yaitu: (1) Pemohon perlindungan yang ditujukan kepada ketua LPSK melalui surat atau permintaan pejabat yang berwenang sebagaimana dimaksud dalam Pasal 4 ayat (3) huruf b, ketua LPSK meneruskan permohonan pemohon kepada UP2 LPSK untuk dilakukan penelitian lebih lanjut mengenai kelengkapan persyaratan sesuai dalam ketentuan peraturan ini; (2) Dalam hal untuk memperoleh pemenuhan kelengkapan berkas permohonan perlindungan, UP2 LPSK dapat berkoordinasi kepada pejabat berwewenang atau yang mengajukan permohonan; (3) Selain persyaratan sebagaimana dimaksud dalam pasal 6 dan pasal 7, UP2 LPSK dapat meminta data atau informasi tambahan yang berkaitan perkaranya antara lain:

a. Hasil Berita Acara Pemeriksaan (BAP);

b. Sifat pentingnya kesaksian dalam perkara;

c. Surat panggilan kepolisian atau Kejaksaan atau Pengadilan;

d. Surat laporan atau informasi kepada pejabat terkait: kepolisian, Komisi Negara, 
pemerintah, pemerintah Daerah, yang berkaitan atas kesaksiannya sebagai pelapor;

e. Surat dari instansi terkait mengenai kasusnya; ${ }^{17}$

Tujuan Pemeriksaan penyidikan tindak pidana adalah menyiapkan hasil pemeriksaan penyidikan, sebagai berkas perkara yang akan diserahkan peyidik kepada penuntut umum sebagai instansi yang bertindak dan berwenang melakukan penuntutan terhadap tindak pidana. Berkas hasil penyidikan itu yang dilimpahkan penuntut umum kepada hakim di sidang pengadilan. Oleh karena itu, apabila penyidik berpendapat, pemeriksaan penyidikan telah selesai dan sempurna, secepatnya mengirimkan berkas perkara hasil penyidikan kepada penuntut umum. Berita Acara Pemeriksaan inilah yang dapat digunakan oleh LPSK guna menilai apakah sesorang itu layak mendapatkan perlindungan dari LPSK atau tidak sesuai tata cara permohonan pengajuan perlindungan (memperoleh perlindungan) dari LPSK. $^{18}$ Ketentuan Pasal 10 Peraturan LPSK No. 6 Tahun 2010 juga mengatur: (1) Pemohon yang mengajukan permohonan dan belum memenuhi persyaratan sebagaimana dimaksud dalam pasal 6 dan pasal 7, diberikan batas waktu untuk melengkapi berkas permohonanannya paling lama 30 (tiga puluh) hari sejak permohonan perlindungan diajukan kepada LPSK; (2) Apabila dalam batas waktu 30 (tiga puluh) hari sebagaimana dimaksud pada ayat (1), pemohon tidak melengkapi persyaratan, permohonannya dinyatakan tidak dapat diterima; (3) Permohonan yang sudah dianggap lengkap oleh UP2 LPSK, dibuatkan risalah permohonan perlindungan. ${ }^{19}$

Selanjutnya diatur dalam Ketentuan Pasal 11 Peraturan LPSK No. 6 Tahun 2010: Data and informasi yang diperoleh sebagaimana dimaksud dalam Pasal 9 ayat (3), apabila masih diperlukan pendalaman terhadap pemohon, UP2 LPSK dapat melakukan investigasi dan/atau klarifikasi baik terhadap pemohon maupun kepada pejabat yang menangani perkaranya. ${ }^{20}$ Berikut Ketentuan Pasal 12: (1) Investigasi

\footnotetext{
${ }^{17}$ Peraturan LPSK No. 6 Tahun 2010.

18 Adami Chazawi, Hukum Pembuktian Tindak Pidana Korupsi (Media Nusa Creative 2018).[65].

19 Peraturan LPSK No. 6 Tahun 2010.

20 ibid.
} 
dan/atau klarifikasi, dilakukan untuk mendalami sifat pentingnya keterangan saksi atau korban, dan/atau tingkat ancaman yang membahayakan diri pemohon; (2) Investigasi dan/atau klarifikasi sebagaimana dimaksud pada ayat (1) dilakukan oleh UP2 LPSK, ditempat atau pada lokasi dimana kedudukan pemohon dan/atau kedudukan pejabat yang menangani perkara yang bersangkutan; (3) Pelaksanaan Investigasi dan/atau klarifikasi sebagaimana dimaksud pada ayat (2), dapat diikuti Anggota LPSK dan/atau dapat menyertakan staf ahli atau staf LPSK lainnya, berdasarkan kebutuhan atau petunjuk ketua LPSK. ${ }^{21}$

Baru setelah melalui mekanisme yang ada, sebagaimana diatur dalam Ketentuan Pasal 13: Hasil dari Investigasi sebagaimana dimaksud dalam Pasal 12, merupakan bagian risalah permohonan perlindungan dan dipertanggungjawabkan oleh UP2 LPSK, untuk diajukan dalam Rapat Paripurna Anggota. ${ }^{22}$ Dan Ketentuan Pasal 14 menegaskan: Rapat Paripurna Anggota LPSK, membahas permohonan pemohon perlindungan, untuk diambil keputusan diterima atau ditolaknya permohonan pemohon. Apabila diterima, proses final sesuai Ketentuan Pasal 20 Peraturan LPSK No. 6 Tahun 2010 adalah menandatangani perjanjian perlindungan, pemohon wajib memahami konsep perjanjian perlindungan yang berisi materi sebagai berikut:

a. Komparasi, yaitu hal yang menjelaskan kedudukan Para Pihak;

b. Resital, yaitu hal yang menjelaskan posisi dan/atau kewenangan Para Pihak;

c. Hal yang mendasari dalam pembuatan perjanjian;

d. Klasifikasi perlindungan;

e. Bentuk perlindungan;

f. Hak dan kewajiban para Pihak;

g. Batas waktu perjanjian atau berhentinya perlindungan;

h. Perubahan / Addendum; dan

i. Anggaran. ${ }^{23}$

Dalam hal mekanisme diatas sudah dilalui, maka saksi pelapor (whistleblower) khususnya pada tindak pidana korupsi berhak mendapatkan status sebagai saksi terlindung LPSK. Hal inilah yang penulis ingin sampaikan sebagai bentuk jawaban
${ }^{21}$ ibid.
22 ibid.
23 ibid. 
dari masalah perlindungan hukum bagi saksi pelapor atau whistleblower atas kesaksiannya memberikan keterangan pada suatu perkara tindak pidana korupsi yang diketahuinya.

\section{Kesimpulan}

Saksi pelapor (whistleblower: saksi pengungkap fakta) didefinisikan sebagai seorang yang memberikan bantuan kepada aparat penegak hukum dalam bentuk pemberian informasi penting, bukti-bukti yang kuat, atau keterangan di bawah sumpah yang dapat mengungkap suatu tindak pidana termasuk korupsi, dimana dia melaporkan pihak yang terlibat dalam tindak pidana tersebut baik perorangan maupun badan hukum atas suatu tindak pidana yang dilaporkannya. Dalam hal ini, statusnya berhak mendapatkan perlindungan hukum yang sesuai

Instrumen perlindungan hukum yang ada, sudah diatur secara jelas baik melalui Undang-Undang Pemberantasan Tindak Pidana Korupsi, sampai UndangUndang Perlindungan Saksi dan Korban. Dalam praktik pelaksanaannya LPSK harus benar-benar memastikan sesuai prosedur yang telah diatur dalam UndangUndang No. 31 Tahun 2014 dan Peraturan LPSK No. 6 Tahun 2010, termasuk memperhatikan Surat Edaran Mahkamah Agung No. 4 Tahun 2011, supaya jika menemukan saksi pelapor (Whistleblower) perkara tindak pidana korupsi maka bisa dengan baik dipastikan apakah pengajuan permohonan yang telah diajukan layak diterima atau tidak, lebih lanjut agar saksi pelapor bisa memberikan keteranganketerangannya guna membantu upaya mencari kebenaran materiil dari proses pemeriksaan perkara-perkara tindak pidana korupsi yang ada.

Menurut Ketentuan Pasal 31 Undang-Undang No. 31 Tahun 1999 diatur: (1) Dalam penyidikan dan pemeriksaan di sidang pengadilan, saksi dan orang lain yang bersangkutan dengan tindak pidana korupsi dilarang menyebut nama atau alamat pelapor, atau hal-hal lain yang memberikan kemungkinan dapat diketahuinya identitas pelapor; (2) Sebelum pemeriksaan dilakukan, larangan sebagaimana dimaksud dalam ayat (1) diberitahukan kepada saksi dan orang lain tersebut. Guna kepentingan perlindungan saksi pelapor (whistleblower), maka penerapan hukum 
dari Ketentuan Pasal 5, Pasal 10, dan Pasal 28 ayat (3) Undang-Undang No. 31 Tahun 2014 serta Ketentuan Peraturan LPSK No. 6 Tahun 2010 Tentang Tata Cara Pemberian Perlindungan Saksi dan Korban harus bisa diterapkan agar pemberian perlindungan bagi saksi pelapor (whistleblower) dapat diberikan secara optimal dan memehuni unsur kepastian hukum.

Pengadilan apabila perkara yang berkaitan dengan saksi pelapor (whistleblower) sudah masuk pada pemeriksaan di sidang pengadilan, baiknya memperhatikan dan menerapkan Ketentuan Surat Edaran Mahkamah Agung No. 4 Tahun 2011 Tentang Perlakuan Bagi Pelapor Tindak Pidana (Whistleblower) dan Saksi Pelaku Yang Bekerjasama (Justice Collaborator) Di Dalam Perkara Tindak Pidana Tertentu.

\section{Daftar Bacaan}

\section{Buku}

Andi Hamzah, Hukum Acara Pidana Indonesia (Sinar Grafika 2016).

Adami Chazawi, Hukum Pembuktian Tindak Pidana Korupsi (Media Nusa Creative 2018).

Didik Endro Purwoleksono, Hukum Pidana (Airlangga University Press 2013).

Didik Endro Purwoleksono, Hukum Acara Pidana (Airlangga University Press 2015).

Robert K, Aris Irawan, Hukum Perlindungan Saksi Dalam Pemberantasan Tindak Pidana Korupsi (Thafa Media 2019).

R. Wiyono, Tindak Pidana Korupsi Di Indonesia (Alumni 1982).

\section{Jurnal}

Bastianto Nugroho, 'Peranan Alat Bukti Dalam Perkara Pidana Dalam Putusan Hakim Menurut Kuhap' (2017) 32 Yuridika.

\section{Perundang-undangan}

Undang-Undang Nomor 31 Tahun 1999 Tentang Pemberantasan Tindak Pidana 
Korupsi (Lembaran Negara Republik Indonesia Tahun 1999 Nomor 140 Tambahan Lembaran Negara Nomor 3874).

Undang-Undang Nomor 20 Tahun 2001 Tentang Perubahan Atas Undang-Undang Nomor 31 Tahun 1999 Tentang Pemberantasan Tindak Pidana Korupsi (Lembaran Negara Republik Indonesia Tahun 2001 Nomor 134 Tambahan Lembaran Negara Nomor 4150).

Undang-Undang Nomor 7 Tahun 2006 Tentang Pengesahan United Nations Convention Against Corruption (UNCAC) (Lembaran Negara Republik Indonesia Tahun 2006 Nomor 32 Tambahan Lembaran Negara Nomor 4620).

Undang-Undang Nomor 31 Tahun 2014 Tentang Perubahan Atas Undang-Undang Nomor 13 Tahun 2006 Tentang Perlindungan Saksi dan Korban (Lembaran Negara Republik Indonesia Tahun 2014 Nomor 294 Tambahan Lembaran Negara Nomor 5602).

Surat Edaran Mahkamah Agung Nomor 4 Tahun 2011 Tentang Perlakuan Bagi Pelapor Tindak Pidana (Whistleblower) dan Saksi Pelaku yang Bekerjasama (Justice Collaborators) Di Dalam Perkara Tindak Pidana Tertentu.

Peraturan LPSK No. 6 Tahun 2010 (Berita Negara Republik Indonesia Tahun 2010 Nomor 502). 
Ilham Rahmansyah: Perlindungan Hukum Saksi

--halaman ini sengaja dibiarkan kosong-- 